\title{
GROWTH AND FLOWERING OF Helleborus argutifolius (Viviani) GROWN IN POTS DEPENDING ON SUBSTRATE TYPE
}

\author{
Monika Henschke*, Piotr Czuchaj, Stanisława Szczepaniak \\ Department of Ornamental Plants, Poznań University of Life Sciences \\ Dąbrowskiego 159, 60-594 Poznań, Poland \\ e-mail*: mohen@up.poznan.pl
}

Received: 29.10 .2013

\begin{abstract}
An experiment was conducted on the effect of substrate type on growth of Corsican hellebore (Helleborus argutifolius Viviani). Plants were grown for two years in pots with substrates whose components included Klasmann highmoor peat and Hartmann highmoor peat, mineral soil, expanded clay and perlite at various volumetric ratios. Vegetative growth and flowering were observed in hellebores. It was shown that substrates exhibited a varied effect on plant growth. Corsican hellebore in a substrate with a considerable addition of mineral soil was lower, but more branched, and it did not form inflorescences. An optimal medium for growing $H$. argutifolius in pots was Hartmann's de-acidified peat + mineral soil (1:1 v:v). In this medium vegetative growth of plants was extensive, flowering was early and abundant, and long peduncles were produced.
\end{abstract}

Key words: Helleborus argutifolius, ornamental plant, cultivation, peat, mineral soil, number of leaves, flower quality

\section{INTRODUCTION}

In Europe in the production of ornamental plants to be used in interior decoration an increasing role is played by pot plants, particularly species with ornamental flowers. These plants are imported from countries with a warmer climate in much lower amounts than is the case with cut flowers. Thus, they do not constitute significant competition for domestic production. Horticultural producers select species with small thermal requirements and a short production cycle. For this reason, the importance of hellebores has increased recently, as different studies, including cultivation trials, have been conducted on this species [1-6]. Hellebores are herbaceous perennials in which flowering may be accelerated during a culture period of as little as 4-6 weeks in a greenhouse at a temperature of $12-16^{\circ} \mathrm{C}$ for a very attractive season, i.e. Christmas [7,8]. However, within the genus Helleborus there are several species differing considerably in terms of their cultivation requirements, particularly the type of substrate. According to Springer [9], commercially available substrates include those based on white Irish peat with clay, perlite, coir and sand.

A standard growing medium in many pot cultures is the peat substrate. This medium exhibits several highly advantageous properties [10]. However, natural resources of highmoor peat are slowly being depleted. Already in the 90s the UK government imposed restrictions on the use of peat as an independent medium [11]. Other substrates such as coir or compost are being researched to replace peat $[12,13]$. Many of these new components of substrates have proved to be surprisingly promising [11]. Additionally, there is a trend to reintroduce the use of components which were used for years before, such as perlite, expanded clay or hortisols. The type of substrates used, due to their physical properties, has a considerable effect on plant growth and flowering [14-17].

The aim of the study was to assess the effect of substrate type on growth and flowering of Corsican hellebore in the first and second years of pot culture.

\section{MATERIALS AND METHODS}

An experiment was conducted at the Marcelin Experimental Station of the Poznan University of Life Sciences to determine the effect of substrate type on growth of Corsican hellebore (Helleborus argutifolius Viviani). Young plants produced in multitrays with 72 pots of $4 \mathrm{~cm}^{3}$ were supplied on 26 April 2006 by Syngenta Sp. z o.o. Seedlings were uniform, at that time 
with 3.0-3.3 true leaves. Plants were transplanted on 26 April 2006 and then again on 27 March 2007 to pots of $1.0 \mathrm{dm}^{3}$ and $2.1 \mathrm{dm}^{3}$, respectively. In both years plants were grown in seven substrates, i.e. Hartmann's de-acidified peat, Klasmann's de-acidified peat, Hartmann's de-acidified peat with mineral soil at a 1:1 ratio (v:v), Klasmann's de-acidified peat with mineral soil at a 1:1 ratio (v:v), Klasmann's de-acidified peat with mineral soil at a 1:2 ratio (v:v), Klasmann's de-acidified peat with mineral soil and with expanded clay at a 1:1:1 ratio (v:v:v), Klasmann's de-acidified peat with mineral soil and perlite at a 1:1:1 ratio (v:v:v). Peats from two companies were used to compose the substrates. They are characterized by bright color and particle sizes 10-20 mm (Hartmann) and 0-25 mm (Klasmann). Hartmann's peat come from Lithuania and Latvia, while Klasmann's peat from Germany, the Baltic States and Ireland. Both peat sources with $\mathrm{pH} 3.91$ were limed on the basis of the neutralization curve to $\mathrm{pH}$ 5.90-6.04 using $\mathrm{CaCO}_{3}$ at a dose of $5.0 \mathrm{~g}$ $\times \mathrm{dm}^{3}$ (substrate) peat. Mineral soil was light loamy sand. The expanded clay used had a grain size of 4-16 mm. Young hellebores were grown in a greenhouse for one month, while older plants were grown in a hotbed with a shading mat and a mulching mat. For the winter period, beginning of November through March, the plants were transferred to an unheated plastic tunnel. In the second year of culture, from the beginning of December, after cooling for 6 weeks at a temperature of about $5.0^{\circ} \mathrm{C}$ the plants were placed in the greenhouse at a temperature of about $13.0^{\circ} \mathrm{C}$ to accelerate flowering. The plants were watered by hand as needed. The values of $\mathrm{pH}$ and $\mathrm{EC}$ of the substrates are provided in Table 1. The ready-to-use substrate mixtures were supplemented with $2.5 \mathrm{~g} \times \mathrm{dm}^{3}$ of the fertilizer Osmocote Plus 5-6 M (15:10:12). One month after transplanting, fertigation with Peters Professional PL Special (15:11:29) was applied at a concentration of $0.15 \%$ (100 ml per pot) and it was repeated every 2 weeks until the end of August.

Plant measurements consisted in the determination of the number of shoots, number of leaves and plant height determined twice during the growing period. The height was measured from the base to the highest part of the plant. In 2006 plants were measured on 26 July and 26 September, while in 2007 it was on 13 August and 13 October. Flowering was observed only in 2007, since in 2006 very few specimens blossomed. At the beginning of flowering, flower diameter and peduncle length were measured. At full bloom, the number of flowers and longevity of flower were determined. The day on which the first flower opened on the plant was considered to be the beginning of flowering, and when half of the buds opened it was considered full flowering. The results of the measurements were subjected to a one-way analysis of variance using the Duncan test at a significance level of 0.05. One factor level (substrate type) comprised 10 replications (10 plants). The date of beginning of flowering and the date of full blooming were calculated using the weighted average.

Table 1

Substrates used in experiment

\begin{tabular}{lcc}
\hline \multicolumn{1}{c}{ Type of substrate } & pH & EC [mS $]$ \\
\hline Hartmann's de-acidified peat & 5,90 & 0,43 \\
Hartmann's de-acidified peat + mineral soil (1:1) & 6,10 & 0,45 \\
Klasmann's de-acidified peat & 6,04 & 0,45 \\
Klasmann's de-acidified peat + mineral soil (1:1) & 6,15 & 0,47 \\
Klasmann's de-acidified peat + mineral soil (1:2) & 6,35 & 0,53 \\
Klasmann's de-acidified peat + mineral soil + expanded clay (1:1:1) & 6,37 & 0,50 \\
Klasmann's de-acidified peat + mineral soil +perlite (1:1:1) & 6,41 & 0,51 \\
\hline
\end{tabular}

\section{RESULTS}

Our experiment showed a varied effect of substrates on $H$. argutifolius growth (Table 2). In the second year of cultivation when flowered plants were ready for sell, plants grown on Klasmann's de-acidified peat had more shoots than Klassman's de-acidified peat + mineral soil + expanded clay (1:1:1 v:v:v). Number of shoots of plants grown in Klasmann's de-acidified peat did not differ significantly from that obtained on the mixture Klasmann's de-acidified peat + mineral soil
(1:2 v:v) and also on Hartmann's substrates. Plants grown in Klasmann's de-acidified peat (14.6) had the greatest number of leaves in September of the first year of growth. In the second year of cultivation at the end of the growing season, plants grown in Klasmann's de-acidified peat continued to have more leaves. After flowering, all plants reached a height of $14.0-18.5 \mathrm{~cm}$; it was a favorable result in pot cultivation. Plants were shorter in Klasmann's de-acidified peat + mineral soil $(1: 2 \mathrm{v}: \mathrm{v})$ than in the other substrates where they were similar in height. 
Table 2

The number of shoots, number of leaves and height of Helleborus argutifolius in the two years of pot cultivation depending on substrate type

\begin{tabular}{|c|c|c|c|c|c|c|c|c|c|c|}
\hline \multirow{4}{*}{ Type of substrate } & \multirow{2}{*}{\multicolumn{2}{|c|}{$\begin{array}{c}\text { Number of shoots } \\
\text { Second year of } \\
\text { pot cultivation }\end{array}$}} & \multicolumn{4}{|c|}{ Number of leaves } & \multicolumn{4}{|c|}{ Height of plant } \\
\hline & & & \multicolumn{2}{|c|}{$\begin{array}{l}\text { First year of pot } \\
\text { cultivation }\end{array}$} & \multicolumn{2}{|c|}{$\begin{array}{l}\text { Second year of } \\
\text { pot cultivation }\end{array}$} & \multicolumn{2}{|c|}{$\begin{array}{l}\text { First year of pot } \\
\text { cultivation }\end{array}$} & \multicolumn{2}{|c|}{$\begin{array}{l}\text { Second year of } \\
\text { pot cultivation }\end{array}$} \\
\hline & \multicolumn{10}{|c|}{ Date of measurement } \\
\hline & 13.08 & 16.10 & 26.07 & 26.09 & 13.08 & 16.10 & 26.07 & 26.09 & 13.08 & 16.10 \\
\hline Hartmann's de-acidified peat & $2,5 a b^{*}$ & $2,6 \mathrm{abc}$ & $6,1 \mathrm{a}$ & $11,4 \mathrm{a}$ & $23,2 \mathrm{bc}$ & $22,5 \mathrm{ab}$ & $12,1 \mathrm{ab}$ & $11,1 \mathrm{a}$ & $19,9 \mathrm{c}$ & $17,8 \mathrm{~b}$ \\
\hline $\begin{array}{l}\text { Hartmann's de-acidified peat } \\
+ \text { mineral soil }(1: 1)\end{array}$ & $2,4 \mathrm{ab}$ & $2,4 \mathrm{abc}$ & $5,8 \mathrm{a}$ & $13,9 \mathrm{bc}$ & $22,4 \mathrm{abc}$ & $20,7 \mathrm{ab}$ & $12,2 \mathrm{ab}$ & $14,7 \mathrm{bc}$ & $21,1 \mathrm{c}$ & $17,4 \mathrm{~b}$ \\
\hline Klasmann's de-acidified peat & $3,0 \mathrm{~b}$ & $3,4 \mathrm{c}$ & $6,0 \mathrm{a}$ & $14,6 \mathrm{c}$ & $24,3 \mathrm{c}$ & $26,1 \mathrm{~b}$ & $13,2 \mathrm{~b}$ & $14,1 \mathrm{bc}$ & $19,5 \mathrm{bc}$ & $18,5 \mathrm{~b}$ \\
\hline $\begin{array}{l}\text { Klasmann's de-acidified peat } \\
+ \text { mineral soil }(1: 1)\end{array}$ & $2,3 \mathrm{ab}$ & $2,2 \mathrm{ab}$ & 5,9 a & $13,0 \mathrm{abc}$ & $18,3 \mathrm{ab}$ & $19,7 \mathrm{a}$ & $11,4 \mathrm{ab}$ & $15,6 \mathrm{c}$ & $15,6 \mathrm{a}$ & $15,6 \mathrm{ab}$ \\
\hline $\begin{array}{l}\text { Klasmann's de-acidified peat } \\
+ \text { mineral soil }(1: 2)\end{array}$ & $2,6 \mathrm{ab}$ & $2,8 \mathrm{bc}$ & $5,2 \mathrm{a}$ & $12,0 \mathrm{ab}$ & $17,6 \mathrm{a}$ & $20,5 \mathrm{ab}$ & $9,8 \mathrm{a}$ & $12,8 \mathrm{ab}$ & $15,1 \mathrm{a}$ & $14,0 \mathrm{a}$ \\
\hline $\begin{array}{l}\text { Klasmann's de-acidified peat } \\
+ \text { mineral soil + expanded clay }(1: 1: 1)\end{array}$ & $1,9 \mathrm{a}$ & $1,7 \mathrm{a}$ & $5,9 \mathrm{a}$ & $11,4 \mathrm{a}$ & $18,1 \mathrm{ab}$ & $18,0 \mathrm{a}$ & $11,2 \mathrm{ab}$ & $15,8 \mathrm{c}$ & $16,1 \mathrm{a}$ & $16,1 \mathrm{ab}$ \\
\hline $\begin{array}{l}\text { Klasmann's de-acidified peat } \\
+ \text { mineral soil + perlite }(1: 1: 1)\end{array}$ & $2,2 \mathrm{ab}$ & $2,2 \mathrm{ab}$ & $5,5 \mathrm{a}$ & $12,4 \mathrm{ab}$ & $19,0 \mathrm{ab}$ & $20,4 \mathrm{ab}$ & $12,1 \mathrm{ab}$ & $15,9 \mathrm{c}$ & $16,8 \mathrm{ab}$ & $16,4 \mathrm{ab}$ \\
\hline
\end{tabular}

* Mean followed by the same letters within the columns are not significantly different at the level of $\alpha=0.05$

The type of growing medium had an effect on flowering of Helleborus argutifolius (Table 3). Plants did not flower in Klasmann's de-acidified peat + soil (1:2 v:v) possibly due to the high bulk density and water holding capacity of this substrate. The other plants started flowering in the last ten days of December. Plants with poorest vegetative growth cultivated in Klasmann's de-acidified peat + mineral soil + expanded clay $(1: 1: 1$ v:v:v) and also in Hartmann's de-acidified peat + mineral soil $(1: 1 \mathrm{v}: \mathrm{v})$ flowered earliest. Plants grown in Hartmann's de-acidified peat + mineral soil $(1: 1 \mathrm{v}: \mathrm{v})$ flowered early and produced many flowers (9.7) with a longevity of 16 days. These plants also had significantly longer shoots in the second year of cultivation than plants cultivated in Klasmann's de-acidified peat + mineral soil $(1: 1 \mathrm{v}: \mathrm{v})$. Plants grown in medium with perlite flowered latest and their blooming lasted longest. The longevity of flowers was relatively shorter when plants were grown in a medium containing Hartmann's de-acidified peat than plants cultivated in Klasmann's de-acidified peat. The vegetative growth of plants cultivated in Klasmann's de-acidified peat + mineral soil + perlite $(1: 1: 1$ v:v:v) was less vigorous, but they had a greater number of open flowers. The diameter of Helleborus flowers in pot cultivation ranged from 5.0 to $5.6 \mathrm{~cm}$ and did not differ significantly between the types of substrates.

Table 3

Flowering of Helleborus argutifolius in the second year of pot cultivation depending on type of substrate

\begin{tabular}{|c|c|c|c|c|c|c|}
\hline Type of substrate & $\begin{array}{l}\text { Begining of } \\
\text { flowering }\end{array}$ & $\begin{array}{l}\text { Full } \\
\text { flowering }\end{array}$ & $\begin{array}{l}\text { The life of a } \\
\text { flower (days) }\end{array}$ & $\begin{array}{l}\text { Flower } \\
\text { diameter }\end{array}$ & $\begin{array}{l}\text { Length on } \\
\text { peduncle } \\
(\mathrm{cm})\end{array}$ & $\begin{array}{c}\text { Number of } \\
\text { open } \\
\text { flowers }\end{array}$ \\
\hline Hartmann's de-acidified peat & 26.12 & 04.01 & $12,0 \mathrm{a}$ & $5,0 a^{*}$ & $19,1 \mathrm{~b}$ & $4,6 \mathrm{a}$ \\
\hline Hartmann's de-acidified peat + mineral soil (1:1) & 22.12 & 09.01 & $16,0 \mathrm{~b}$ & 5,4 a & $18,6 \mathrm{~b}$ & $9,7 \mathrm{a}$ \\
\hline Klasmann's de-acidified peat & 30.12 & 09.01 & $15,0 \mathrm{~b}$ & $5,6 \mathrm{a}$ & $20,4 \mathrm{~b}$ & $4,4 \mathrm{a}$ \\
\hline Klasmann's de-acidified peat + mineral soil $(1: 1)$ & 28.12 & 12.01 & $14,0 \mathrm{~b}$ & $5,1 \mathrm{a}$ & $13,3 \mathrm{a}$ & $6,7 \mathrm{a}$ \\
\hline Klasmann's de-acidified peat + mineral soil $(1: 2)$ & - & - & - & - & - & - \\
\hline $\begin{array}{l}\text { Klasmann's de-acidified peat }+ \text { mineral soil } \\
+ \text { expanded clay }(1: 1: 1)\end{array}$ & 22.12 & 04.01 & $18,0 \mathrm{c}$ & $5,6 \mathrm{a}$ & $16,4 \mathrm{ab}$ & $4,6 \mathrm{a}$ \\
\hline $\begin{array}{l}\text { Klasmann's de-acidified peat }+ \text { mineral soil } \\
+ \text { perlite }(1: 1: 1)\end{array}$ & 01.01 & 17.01 & $12,0 \mathrm{a}$ & $5,4 \mathrm{a}$ & $16,8 \mathrm{ab}$ & $16,0 \mathrm{~b}$ \\
\hline
\end{tabular}

* For explanation, see table 2 


\section{DISCUSSION}

Our experiment showed the effect of substrates on $H$. argutifolius growth. Plants cultivated in Klasmann's de-acidified peat and Klasmann's de-acidified peat + mineral soil $(1: 2, \mathrm{v}: \mathrm{v})$ or in Hartmann's de-acidified peat and Hartmann's de-acidified peat + mineral soil $(1: 1, \mathrm{v}: \mathrm{v})$ had the greatest number of shoots. In contrast, in an experiment by Szczepaniak and K ozik [18] plants of Coreopsis grandiflora had a greater number of shorter lateral branchings when they were grown in a mixture of de-acidified peat with mineral soil $(1: 1, v: v)$ than in de-acidified peat alone. In our experiment, the medium with perlite had a negative effect on the number of shoots in October. Similarly, Ercis li et al. [19] obtained strawberry 'Fern' with a higher number of runners and with a higher number of crowns on runners in peat than in medium with peat and perlite $(1: 1 \mathrm{v}: \mathrm{v})$.

In our experiment, plants cultivated in Klasmann's de-acidified peat had the greatest number of leaves for two years. However, according to a survey conducted among the members of the Finnish Association of Nurserymen Ornamental Plants, most of them negatively commented on Sphagnum peat substrates. They believe that in comparison to mineral soil Sphagnum peat substrates dry faster in the root zone and become hydrophobic, which negatively affects the growth of plants [20].

In our experiment, after flowering all plants reached a height of up to $20 \mathrm{~cm}$. It was a favorable result in pot cultivation. In places of natural occurrence, in Corsica and Sardinia, Helleborus argutifolius reaches a height of 90-120 cm. This plant grows commonly on roadsides and in woods in full sun, on fertile and permeable soils. If grown in heavy clay soil, it has a tendency to fall over [21]. The aim of cultivation of perennials in pots is to obtain branched plants with many leaves and a height of $15-20 \mathrm{~cm}$.

The type of growing medium had an effect on flowering of Helleborus argutifolius. The best results were obtained when plants were cultivated in Hartmann's de-acidified peat + mineral soil (1:1 v:v). Plants flowered early and produced many flowers with a longevity of 16 days. In their experiment, S z c z e p a n i $\mathrm{ak}$ and Kozik [18] also obtained more abundantly flowering Coreopsis grandiflora plants when they were grown in the mixture of Kronen's de-acidified peat and mineral soil $(1: 1 \mathrm{v}: \mathrm{v})$ in comparison to their cultivation in Kronen's de-acidified peat alone. However, a positive effect of Kronen's de-acidified peat, in comparison to the mixture of Kronen's de-acidified peat and mineral soil $(1: 2 \mathrm{v}: \mathrm{v})$, on earliness and abundance of flowering was also obtained by $\mathrm{S} \mathrm{zc} z$ e p a n i a k and Ku piec [22] in forced pot culture of Doronicum orientale 'Little Leo', while C z u ch a j and S z c ze pan i ak [23] reported the same trend in pot culture of Gaillardia aristata. However, R e i m a h e r r [24] reported that Christmas rose was best grown in a well-aerated substrate that was permeable and fertile, such as a peat and compost mixture (1:1 v:v) or a mixture of standard peat with a $15 \%$ fibrous peat addition.

The diameter of Helleborus argutifolius flowers in our study ranged from 5.0 to $5.6 \mathrm{~cm}$ and this result was satisfactory, because this species produces flowers with a diameter of $2.5-5.0 \mathrm{~cm}$ at natural sites [21].

\section{CONCLUSIONS}

1. Klasmann's de-acidified peat or Hartmann's deacidified peat as a component of substrates for growing Helleborus argutifolius in pots should constitute more than one third of the volume of the substrate.

2. Perlite as a component of substrate increases the abundance of flowering.

3. The optimal substrate for cultivation of growing $H$. argutifolius in pots is Hartmann's de-acidified peat + mineral soil $(1: 1 \mathrm{v}: \mathrm{v})$. Vegetative growth of plants cultivated in this medium is extensive, flowering is early and abundant, and long peduncles are produced.

\section{Acknowledgements}

Work was financially supported by Ministry of Science and Higher Education as part of the research to sustain the research potential of the Department of Ornamental plants at the University of Life Sciences in Poznan. The plant material for research was provided by Syngenta Sp. z o.o.

\section{Authors' contributions}

The following declarations about authors' contributions to the research have been made: concept of the study: $\mathrm{MH}$; field research: $\mathrm{MH}, \mathrm{PCz}$; data analyses: $\mathrm{MH}, \mathrm{PCz}$; writing of the manuscript: $\mathrm{MH}, \mathrm{PCz}, \mathrm{SSz}$; comments on the manuscript: SSz.

\section{REFERENCES}

1. Kraus HT, Warren SL. Nutrient and pH management programs for nursery production of Helleborus $x$ hybridus. SNA Res Conf. 2002; 47: 18-22.

2. Piskornik M. Production of Christmas Rose young plants from seedlings during one vegetation season. EJPAU. 2003; 6(1): \#05.

3. P iskornik M. Improving Christmas Rose (Helleborus niger L.) young plants production. Acta Sci Pol Hortorum Cultus. 2003; 2(2): 69-74.

4. Lubell JD, Thompson DM, Brand MH. Foliar sprays of benzyladenine increase bud and propagule 
production in Epimedium $x$ rubrum Morren and Helleborus $x$ hybridus L. Propag Ornam Plants. 2005; 5(1): 19-22.

5. Szczepaniak S, Henschke M, Czuchaj P, Kozik E. Growth and flowering of lenten rose (Helleborus orientalis Lam.) depending on the dose of calcium carbonate and top dressing with Peters Professional Special. Acta Sci Pol Hortorum Cultus. 2008; 7(4): 13-22.

6. Henschke M, Szczepaniak S, Czuchaj P, Kozik E. The effect of calcium carbonate and top dressing with Peters Professional Special on the growth and flowering of Helleborus lividus Aiton. Folia Hort. 2009; 21(1). http://dx.doi.org/10.2478/fhort-2013-0130

7. Pogroszewska E. Przyspieszona uprawa ciemiernika ogrodowego (Helleborus $x$ hybridus Hort.) w szkalrni. Nowe rośliny i technologie w ogrodnictwie. Poznań Agricultural University of Poznań 1996. p. 397-400. (in Polish)

8. Lowder A, Kraus HT, Blazich FA, Warren SL. Day/night temperatures influence growth and photosynthesis during containerized production of selected species of $\mathrm{Hel}$ leborus (Hellebores). J Env Hortic. 2010; 28(3): 179-186.

9. S pringer P. Stabile Strukturen machen das Rennen. DeGa. 2005; 13: 17-19. (in German)

10. Schmilewski G. Growing medium constituents used in the EU. Acta Hortic. 2007; 819: 33-45.

11. Czajka E, Szczepaniak S. Wpływ podłoża na wzrost młodych roślin trzech gatunków bylin o ozdobnych liściach. Zesz Probl Post Nauk Rol. 2005; 504: 57-65. (in Polish)

12. Janicka D, Dobrowolska A. Effect of organic media on growth and development of patiola F1 horned violet (Viola cornuta L.). Acta Agrob. 2013; 66(1): 95-104. http:// dx.doi.org/10.5586/aa.2013.011

13. Holmes S. Growing media developments in the UK. Acta Hortic. 2007; 819: 23-26.

14. Michalak B, Hetman J. Wpływ podłożai nawożenia na jakość rozsad jednorocznych roślin kwietnikowych. Zesz Probl Post Nauk Rol. 2002;485:205-216. (in Polish)

15. Michiels P, Hartmann R, Coussens C. Physical properties of peat substrates in an EBB/FLOOD irrigation system. Acta Hortic. 1993; 342: 205-219.

16. Het $\mathrm{m}$ a n J, Wit e k M. The effects of different substrates on flowering of kohleria (Kohleria amabilis Hook.). Acta Agrobot. 2006; 59(1): 405-412. http://dx.doi.org/10.5586/ aa.2006.042

17. Riaz A, Arshad M, Younis A, Raza A, Hameed M. Effects of different growing media on growth and flowering of Zinnia elegans cv. Blue Point. Pak J Bot [Internet]. 2008 [cited 2012 Jun 2]; Available from: http://core.kmi.open.ac.uk/ display/19297867

18. Szczepaniak S, Kozik E. Wpływ rodzaju i objętości podłoża oraz nawozów o spowolnionym działaniu na wzrost młodych roślin nachyłka wielkokwiatowego. The influence of kind of substrate, its volume and slow release fertilizer on the growth of young plants of Coreopsis grandiflora. Rocz AR Pozn Ogrod. 2004; 38: 157-161. (in Polish)

19. Ercisli S, Sahin U, Esitken A, Anapali O. Effects of some growing media on the growth of strawberry cvs. "Camarosa" and "Fern."Acta Agrobot. 2005; 58(1): 185-191. http://dx.doi.org/10.5586/aa.2005.024

20. Kukkonen S, Vestberg M. Nursery growers' experiences of growing media - a Finnish case study. Acta Hortic. 2007; 819: 273-278.

21. Rice G, Strangman E. The gardener's guide to growing hellebores. Portland, OR: Timber Press, Inc.; 2001.

22. Szczepaniak S, Kupiec A. Wrost i kwitnienie omiega wschodniego (Doronicum orientalne Hoffm.) "Little Leo" uprawianego w doniczkach pod osłonami. Zesz Probl Post Nauk Rol. 2002; 483: 245-251. (in Polish)

23. Czuchaj P, Szczepaniak S. Wzrost i kwitnienie gailardii ościstej (Gaillardia aristata Pursh) uprawianej w doniczkach w różnych podłożach. Zesz Probl Post Nauk Rol. 2005; 504: 67-71. (in Polish)

24. Reimherr P. Helleborus niger (Ranunculaceae). Veitshöchheimer Kultur - Information zur Christrose. Gärtnerbörse 1998; 09: 27-29. (in German)

\section{Wzrost i kwitnienie Helleborus argutifolius (Viviani) uprawianego w doniczkach w zależności od rodzaju podłoża}

\section{Streszczenie}

Doświadczenie przeprowadzono na temat wpływu rodzaju podłoża na wzrost ciemiernika korsykańskiego (Helleborus argutifolius Viviani). Rośliny przez dwa lata uprawiano w doniczkach w podłożach, których komponentami były torf wysoki Klasmann i Hartmann, gleba mineralna, keramzyt i perlit, w różnych stosunkach objętościowych. Obserwowano wzrost wegetatywny i kwitnienie ciemierników. Wykazano, że różne podłoża miały wpływ na wzrost roślin. Ciemiernik korsykański w podłożu ze znacznym udziałem gleby mineralnej był niższy, ale bardziej rozkrzewiony i nie tworzył kwiatostanów. Optymalnym podłożem do uprawy $H$. argutifolius w doniczkach był torf odkwaszony Hartmann + gleba mineralna (1:1 v:v). W tym podłożu wzrost wegetatywny roślin był intensywniejszy, kwitnienie było wcześniejsze i obfitsze, a szypuły kwiatostanowe były dłuższe. 
Handling Editor: Elżbieta Weryszko-Chmielewska

This is an Open Access digital version of the article distributed under the terms of the Creative Commons Attribution 3.0 License (creativecommons.org/licenses/by/3.0/), which permits redistribution, commercial and non-commercial, provided that the article is properly cited.

(CThe Author(s) 2014 Published by Polish Botanical Society 